heparinization does not ensure that platelet thrombi cannot form. Heparin (like the coumarins) actively prevents fibrin deposition but does not lessen platelet adhesion and transformation (Sherry, 1971). Although it was not always possible to demonstrate thrombus deposition in the needle when the venous pressures were high, it is possible that clots become dislodged both during dialysis and also when coil blood is returned at the end of dialysis. The contribution made by the actual material of the needle hubs to the net local thrombogenic effect is unpredictable (Scarborough, 1971). Nylon can be markedly thrombogenic (Williams, 1971) but any such effect may be obviated by silicone.

Local rheological characteristics at the hub are likely to have a pronounced effect on thrombogenesis (Brinkhous, 1969). Sudden changes in luminal diameter are likely to bring about boundary layer separation in the blood stream with the formation of a stagnation point (Fox and Hugh, 1966; Leith et al., 1969) and its attendant liability to thrombus formation (Petschek et al., 1967). Both the hub of the plastic hub needle and the cannula have siliconized smooth internal contours, which would be expected to reduce turbulent flow (Whitmore, 1968) and also platelet adhesion of fibrin deposition (Jaques et al., 1946; Perkins et al., 1960). Both the needle of the fistula set and the unmodified alloy needle have haemodynamically disadvantageous projecting edges set in the blood flow path. These would predispose to turbulent flow and thrombus formation irrespective of the material used. Since the modified alloy needle was no better in use than the unmodified one, it would seem that the metal material of the hub could be clot-promoting, thus outweighing the improved flow path, but the surface finish after milling-out was admittedly imperfect.

In general, we conclude that thrombi are the main factor in the production of high venous pressures developing during dialysis, but there are obviously several factors affecting the extent of clot formation. Variation between patients may reflect individual differences in platelet adhesiveness.

This conclusion-platelet thrombus formation, despite heparinization, occurring at the venous end of an extracorporeal arteriovenous shunt-is similar to that described by Shionoya (1927) when working with collodion tubes in rabbits. The internal configuration of the hub of the venous return needle is critical in this context.

Our thanks are due to the staff of the artificial kidney unit for their conscientious participation.

\section{References}

Brinkhous, K. M. (1969). In Thrombosis, ed. S. Sherry, K. M. Brinkhous, E. Genton, and J. M. Stengle, p. 547. Washington, D.C., National Academy of Sciences.

British Standards Institution (1962). British Standard 3387. London, B.S.I.

British Standards Institution (1962). British Standard 3387. Lond
Fox, J. A., and Hugh, A. E. (1966). British Heart fournal, 28, 388.

Jaques, L. B., Fidlar, E., Feldsted, E. T., and Macdonald, A. G. (1946). Canadian Medical Association fournal, 55, 26.

Jorgensen, L., Rowsell, H. C., Hovig, T., and Mustard, J. F. (1967). American Fournal of Pathology, 51, 681.

Leith, W. C., et al. (1969). Transactions. American Society for Artificial Internal Organs, 15, 272.

Mustard, J. F., and Packham, M. A. (1970). Circulation, 42, 1.

Nidus, B. D., Matalon, R., Deutsch, P., and Eisinger, R. P. (1971). Nephron, 8,191

Perkins, H. A., Osborn, J. J., and Gerbode, F. (1960). Fournal of Cardiovascular Surgery, 1, 180.

Petschek, H. E., Kantrowitz, A. R., and Adamis, D. (1967). Proceedings of the Annual Conference on Engineering in Medicine and Biology, 9, 19.6.

Scarborough, D. E. (1971). Current Topics in Pathology, 54, 95.

Sherry, S. (1971). New England fournal of Medicine, 284, 1324.

Shionoya, T. (1927). Fournal of Experimental Medicine, 46, 19.

Stewart, W. K., Goddard, J. D., and Wakefield, W. C. (1969). British Medical fournal, 1, 644 .

Wakefield, W. C., Goddard, J. D., and Stewart, W. K. (1970). Bio-Medical Engineering, 5, 330.

Whitmore, R. L. (1968). Rheology of Circulation, p. 155. Oxford, Pergamon Press.

Williams, D. F. (1971). Bio-Medical Engineering, 6, 205.

\title{
Acute Renal Failure and Open Heart Surgery
}

\author{
E. D. YEBOAH, AVIVA PETRIE, J. L. PEAD
}

British Medical fournal, 1972, 1, 415-418

\section{Summary}

A retrospective study of 428 open heart operations showed the incidence of mild and severe renal failure to be $26 \%$ and $4.7 \%$ respectively. The mortality rate was $38 \%$ in the mild cases and $70 \%$ in the severe cases. Only half of the patients whose death was associated with renal failure showed macroscopic or microscopic renal lesions at necropsy. The patients who developed renal impairment had significantly higher mean preoperative blood urea (40 $\mathrm{mg} / 100 \mathrm{ml}$ ) than the non-renal-failure cases (33 mg/100 ml). Periods of perfusion over 60 minutes, mean perfusion pressures below $80 \mathrm{~mm} \mathrm{Hg}$, and multiple valve replacement operations also increased the incidence of renal failure. There was no statistical correlation

Hammersmith Hospital, London W12 OHS

E. D. YEBOAH, M.B., B.CHIR., F.R.C.S., Formerly Registrar in Cardiac Surgery and now Registrar in Urology

J. L. PEAD, M.B., B.S., M.R.C.PATH., Senior Registrar, Department of Morbid Anatomy

Royal Postgraduate Medical School, London W12 OHS

AVIVA PETRIE, M.sc., Honorary Lecturer in Medical Statistics between the age of individual patients, the degree of cooling, and postoperative blood urea values. There was no evidence to suggest that frusemide or mannitol separately or together influenced the development of renal failure. Peritoneal dialysis was preferred for initial treatment of patients with severe renal failure, and haemodialysis was required only in special cases.

\section{Introduction}

Acute renal failure is a serious complication of operations which involve total body perfusion, but the reported incidence of the complication has varied widely between 2.0 and $13.5 \%$ (Rand et al., 1963; Sawyer et al., 1963; Norman et al., 1964; Yeh et al., 1964; Kulatilake and Shackman, 1965; Porter et al., 1966, 1967).

The present report is based on a retrospective study of 428 open heart operations with total body perfusion carried out on 267 male and 161 female patients aged 5 to 65 years during the period January 1968 to June 1970 (Table I).

The Melrose rotating disc oxygenator was used in 317 cases and Temptrol or Rygg bag bubble oxygenators in 111. The oxygenators were primed with a mixture of $1,500 \mathrm{ml}$ of whole blood (acid citrate dextrose), $500 \mathrm{ml}$ of Hartmann's solution, and $1,000 \mathrm{ml}$ of $5 \%$ dextrose; sodium bicarbonate $60 \mathrm{mEq}$ was added whenever the body surface exceeded $1.3 \mathrm{~m}^{2}$. Flow rates 
TABLE I-Open Heart Operations from fanuary 1968 to fune 1970

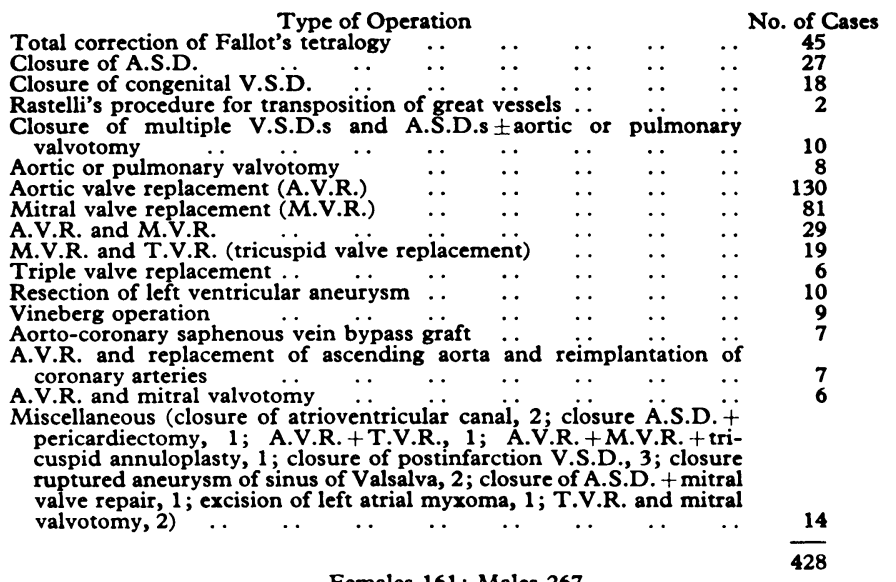

Females 161; Males 267.

were maintained at 2.4-2.6 $1 . / \mathrm{m}^{2}$ during perfusion and body temperatures were kept at $30-33^{\circ} \mathrm{C}$. Mean arterial pressure, central venous pressure, blood oxygen and carbon dioxide tension, serum $\mathrm{pH}$ and electrolytes, and electrocardiograms were monitored throughout. An indwelling urethral catheter was passed before perfusion and mannitol 25-50 g or frusemide 20-40 mg, or mannitol and frusemide, were given into the arterial side of the perfusion circuit whenever the urine flow rate decreased to less than $1 \mathrm{ml} /$ minute after the first 30 minutes of perfusion. After operation the patients were nursed in an intensive care unit and care was taken to ensure that blood and fluid balances were maintained. The operative observations on the circulatory state were continued and 24-hour urine volumes were measured and examined for osmolarity and urea, sodium, potassium, chloride, and creatinine concentrations, while whole blood samples were similarly examined.

For the purposes of this study mild renal failure is defined as blood urea exceeding $80 \mathrm{mg} / 100 \mathrm{ml}$, serum potassium not exceeding $5 \mathrm{mEq} / \mathrm{l}$, and urine output not less than $500 \mathrm{ml} /$ day with decreasing urine urea concentrations, dialysis not being required (Kulatilake and Shackman, 1965; Porter et al., 1966; Selmonsky, 1969).

Severe renal failure is defined as blood urea exceeding $130 \mathrm{mg} /$ $100 \mathrm{ml}$, serum potassium exceeding $5 \mathrm{mEq} / \mathrm{l}$., and urine output less than $500 \mathrm{ml} /$ day, with decreasing urine urea concentrations falling below $500 \mathrm{mg} / 100 \mathrm{ml}$, being dialysis required (Bull et al., 1950; Rand et al., 1963; Sawyer et al., 1963; Norman et al., 1964; Yeh et al., 1964; Kulatilake and Shackman, 1965; Porter et al., 1966, 1967).

\section{Results}

Some degree of renal impairment was observed in $130(30 \%)$ out of 424 patients. In $110(26 \%)$ the renal failure was mild and dialysis was not required. In $20(4.7 \%)$ the renal failure was severe and dialysis was required. Four patients presented with valve disease and renal failure before operation; two of these did not survive aortic and mitral valve replacement respectively; the remaining two had severe renal failure, and haemodialysis was required before operation-one patient with end-stage renal failure and mitral valve regurgitation due to bacterial endocarditis did not survive valve replacement, but the other, with chronic glomerulonephritis, survived aortic valve replacement.

The patients who developed renal impairment had significantly higher mean preoperative blood urea values (mean $40 \mathrm{mg} / 100 \mathrm{ml}$, S.E. of mean $1.3 \mathrm{mg}$ ) than the non-renal-failure cases (mean $33 \mathrm{mg} / 100 \mathrm{ml}$, S.E. of mean $0.6 \mathrm{mg})\left(t_{411}=5.83\right.$, $\mathrm{P}<0.001$ ) (Table II).
TABLE II-Blood Urea Values of 424 Patients Who Had Open Heart Operations

\begin{tabular}{|c|c|c|c|c|}
\hline & \multicolumn{2}{|c|}{$\begin{array}{l}\text { Preoperative } \\
\text { Blood Urea } \\
(\mathrm{mg} / 100 \mathrm{ml})\end{array}$} & \multicolumn{2}{|c|}{$\begin{array}{l}\text { Highest Postoperative } \\
\text { Blood Urea } \\
(\mathrm{mg} / 100 \mathrm{ml})\end{array}$} \\
\hline & $\begin{array}{l}\text { Mean } \\
\text { Values }\end{array}$ & $\underset{\text { Mean }}{\text { S.E. of }}$ & $\begin{array}{l}\text { Mean } \\
\text { Values }\end{array}$ & $\begin{array}{l}\text { S.E. of } \\
\text { Mean }\end{array}$ \\
\hline $\begin{array}{l}\text { All cases } \\
\text { Cases with no renal failure } \\
\text { Mild renal failure } \\
\text { Severe renal failure } \quad \ldots\end{array}$ & $\begin{array}{l}35 \\
33 \\
40 \\
42\end{array}$ & $\begin{array}{l} \pm 0.6 \\
\pm 0.6 \\
\pm 1.2 \\
\pm 2.9\end{array}$ & $\begin{array}{r}82 \\
48 \\
135 \\
276\end{array}$ & $\begin{array}{l} \pm 3 \cdot 5 \\
\pm 0 \cdot 9 \\
\pm 6 \\
\pm 22\end{array}$ \\
\hline
\end{tabular}

Death occurred in $42(38 \%)$ of the 110 cases of mild renal failure, although there was good recovery of renal function in 12 of the 42 fatal cases. Fourteen of the 20 patients with severe renal failure died. Two fatalities were directly attributable to peritoneal dialysis, one from haemorrhage as a result of the puncture of the inferior vena cava during the insertion of a peritoneal catheter and one from candida peritonitis and septicaemia. One patient died from pulmonary oedema and left ventricular failure during haemodialysis.

Necropsies carried out in $\mathbf{4 0}$ cases with antemortem diagnosis of renal failure revealed acute tubular necrosis in 10, renal infarction in seven, and renal pyaemic abscesses in two. In the remaining 21 cases (all with antemortem diagnosis of mild renal failure) there was no macroscopic or microscopic evidence of renal disease.

The incidence of renal impairment was related to the duration of perfusion (Chart and Table III) and there was an increased incidence when the duration of perfusion exceeded $60,90,120$, $150,180,210$, and 240 minutes. Statistical analysis has also shown that the incidence of severe renal failure was greater when perfusion exceeded 120 minutes $\left(\chi_{1}^{2}=8 \cdot 73, P=0 \cdot 003\right)$.

TABLE III-Duration of Perfusion and Incidence of Acute Renal Failure (Cumulative Figures)

\begin{tabular}{|c|c|c|c|c|c|c|}
\hline \multicolumn{3}{|c|}{$\begin{array}{l}\text { Duration of Perfusion } \\
\text { in Minutes }\end{array}$} & \multirow{2}{*}{$\begin{array}{c}\begin{array}{c}\text { Total } \\
\text { No. of } \\
\text { Cases }\end{array} \\
\begin{array}{r}50 \\
364\end{array}\end{array}$} & \multirow{2}{*}{$\begin{array}{c}\begin{array}{c}\text { Mild } \\
\text { Renal } \\
\text { Failure }\end{array} \\
4 \\
104\end{array}$} & \multirow{2}{*}{$\begin{array}{c}\begin{array}{c}\text { Severe } \\
\text { Renal } \\
\text { Failure }\end{array} \\
0 \\
20\end{array}$} & \multirow{2}{*}{$\begin{array}{c}\begin{array}{c}\text { Statistical } \\
\text { Analysis } \dagger\end{array} \\
\begin{array}{r}\chi_{1}^{2}=12.79 \\
P<0.001\end{array}\end{array}$} \\
\hline $\begin{array}{l}0-60 \\
\text { Over } 60\end{array}$ & $\because$ & $\begin{array}{l}\ldots \\
\ldots\end{array}$ & & & & \\
\hline $\begin{array}{l}0-90 \\
\text { Over } 90\end{array}$ & $\because$ & $\because$ & $\begin{array}{l}123 \\
291\end{array}$ & $\begin{array}{l}25 \\
83\end{array}$ & $\begin{array}{r}2 \\
18\end{array}$ & $\begin{aligned} x_{1}^{2} & =6.62 \\
\mathbf{P} & =0.01\end{aligned}$ \\
\hline $\begin{array}{l}0-120 \ldots \\
\text { Over } 120\end{array}$ & . & . & $\begin{array}{l}245 \\
169\end{array}$ & $\begin{array}{l}52 \\
56\end{array}$ & $\begin{array}{r}5 \\
15\end{array}$ & $\begin{array}{l}x_{1}^{2}=15.59 \\
P<0.001\end{array}$ \\
\hline $\begin{array}{l}0-180 \ldots 0 \\
\text { Over } 180\end{array}$ & 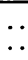 & $\because$ & $\begin{array}{r}351 \\
63\end{array}$ & $\begin{array}{l}84 \\
24\end{array}$ & $\begin{array}{r}14 \\
6\end{array}$ & $\begin{aligned} x_{1}^{2} & =8.80 \\
P & =0.003\end{aligned}$ \\
\hline $\begin{array}{l}0-240 \\
\text { Over } 240\end{array}$ & $\because$ & 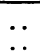 & $\begin{array}{r}407 \\
7\end{array}$ & $\begin{array}{r}103 \\
5\end{array}$ & $\begin{array}{r}19 \\
1\end{array}$ & $\begin{aligned} x_{1}^{2} & =7.24 \\
P & =0.007\end{aligned}$ \\
\hline $\begin{array}{l}\text { Total No. } \\
\text { with availa }\end{array}$ & & & $414+2 *$ & $\begin{array}{l}108 \\
(26 \%)\end{array}$ & $\begin{array}{l}20+2 * \\
(4 \cdot 8 \%)\end{array}$ & \\
\hline
\end{tabular}

*Preoperative haemodialysis.

t $x^{2}$ values for all cases (severe and mild)'renal failure against no renal failure cases.

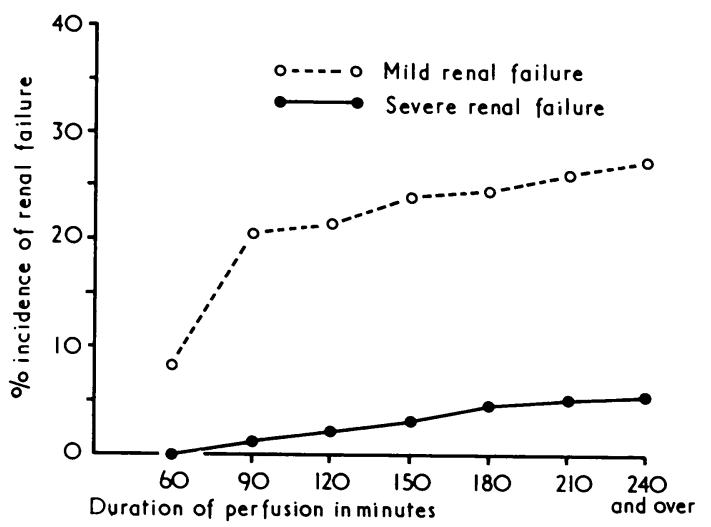

Duration of perfusion in open heart surgery and incidence of renal failure (cumulative figures). In addition $x_{3}^{3}=5 \cdot 78$, $\mathbf{P}=0.02$ (for degree of renal failure). 
When the operations involved multiple valve replacement the incidence of renal impairment was 28 out of $56(50 \%)$-in 18 $(32 \%)$ the renal failure was mild but in $10(18 \%)$ it was severebut these represented the patients with long-standing cardiac disease needing complicated operations requiring longer periods of perfusion.

Provided the mean perfusion pressure was maintained at or above $80 \mathrm{~mm} \mathrm{Hg}$ the incidence of subsequent renal impairment did not exceed $12.5 \%$; but when the mean perfusion pressure was less than $80 \mathrm{~mm} \mathrm{Hg}$ for over 30 minutes the increased incidence was significant $\left(\chi_{1}^{2}=8 \cdot 66, P=0 \cdot 003\right.$, Table IV).

TABLE IV-Lowest Mean Perfusion Pressure and Incidence of Renal Impairment (Cumulative Figures)

\begin{tabular}{|c|c|c|c|c|c|c|c|}
\hline \multicolumn{4}{|c|}{$\begin{array}{l}\text { Mean Perfusion } \\
\text { Pressure in } \mathrm{mm} \mathrm{Hg} \\
\text { for } 30 \mathrm{~min} \\
\text { or more }\end{array}$} & \multirow{2}{*}{$\begin{array}{c}\begin{array}{c}\text { Total } \\
\text { No. of } \\
\text { Cases }\end{array} \\
\begin{array}{c}49 \\
332\end{array}\end{array}$} & \multirow{2}{*}{$\begin{array}{c}\begin{array}{c}\text { Mild } \\
\text { Renal } \\
\text { Failure }\end{array} \\
4 \\
98\end{array}$} & \multirow{2}{*}{$\begin{array}{c}\begin{array}{c}\text { Severe } \\
\text { Renal } \\
\text { Failure }\end{array} \\
2 \\
16\end{array}$} & \multirow{2}{*}{$\begin{array}{c}\begin{array}{c}\text { Statistical } \\
\text { Analysis } \dagger\end{array} \\
\begin{array}{c}x_{1}^{2}=8.66 \\
\mathbf{P}=0.003\end{array}\end{array}$} \\
\hline $\begin{array}{l}\geqslant 80 \\
<80\end{array}$ & $\begin{array}{l}\cdots \\
\cdots\end{array}$ & $\begin{array}{l}\text {. } \\
\text {. }\end{array}$ & $\begin{array}{l}\cdots \\
\cdots\end{array}$ & & & & \\
\hline$\geqslant 70$ & $\because$ & $\therefore$ & $\because$ & $\begin{array}{l}160 \\
221\end{array}$ & $\begin{array}{l}36 \\
66\end{array}$ & $\begin{array}{r}6 \\
12\end{array}$ & $\begin{aligned} x_{1}^{2} & =3.11 \\
\mathbf{P} & =0.08\end{aligned}$ \\
\hline$\geqslant 60$ & 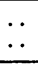 & $\because$ & $\because$ & $\begin{array}{l}260 \\
121 \\
\end{array}$ & $\begin{array}{l}69 \\
33 \\
\end{array}$ & $\begin{array}{l}9 \\
9 \\
\end{array}$ & $\begin{aligned} x_{1}^{2} & =0.64 \\
P & =0.42\end{aligned}$ \\
\hline $\begin{array}{l}\geqslant 50 \\
<50\end{array}$ & 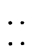 & $\begin{array}{l}\ldots \\
\therefore\end{array}$ & $\therefore$ & $\begin{array}{r}371 \\
10\end{array}$ & $\begin{array}{r}98 \\
4\end{array}$ & $\begin{array}{r}17 \\
1\end{array}$ & $\begin{aligned} x_{1}^{2} & =0.54 \\
P & =0.45\end{aligned}$ \\
\hline$\geqslant 40$ & $\begin{array}{l}\ldots \\
\cdots\end{array}$ & $\therefore$ & $\begin{array}{l}\cdots \\
\cdots\end{array}$ & $\begin{array}{r}378 \\
3\end{array}$ & $\begin{array}{r}101 \\
1\end{array}$ & $\begin{array}{r}18 \\
0\end{array}$ & $\begin{aligned} \chi_{1}^{2} & =0.31 \\
\mathbf{P} & =0.58\end{aligned}$ \\
\hline \multicolumn{4}{|c|}{$\begin{array}{l}\text { Total No. of patients } \\
\text { with available data }\end{array}$} & $381+2 *$ & $\begin{array}{c}102 \\
(26 \cdot 7 \%)\end{array}$ & $\begin{array}{l}18+2 * \\
(4 \cdot 7 \%)\end{array}$ & \\
\hline
\end{tabular}

*Preoperative haemodialysis.

$+\chi^{2}$ values for all cases (severe and mild) renal failure against no renal failure cases.

Mannitol had been administered during perfusion to 81 patients who subsequently developed renal impairment; of 70 with mild renal failure $45(64 \%)$ recovered spontaneously, but of 11 patients with severe renal failure only one recovered. There was no apparent relation between the administration of mannitol or frusemide separately or together and the incidence of renal failure $\left(\chi_{2}^{2}=0.59, \mathrm{P}>0.05\right)$ or severity of renal failure $\left(\chi_{2}^{2}=0 \cdot 10, P>0.05\right)$.

Restitution of renal function occurred with conservative measures alone in 80 of the 110 cases of mild renal failure although 12 of the patients subsequently died. Peritoneal dialysis was used whenever possible and 15 out of 22 patients were treated in this way. Six (including two who had preoperative renal failure) were managed by both peritoneal dialysis and haemodialysis. Only one patient was treated by haemodialysis alone.

\section{Discussion}

Our results show that the incidence of mild renal failure, as defined, in patients subjected to open heart surgery with total body perfusion was $26 \%$ and the incidence of severe renal failure, as defined, was less than 5\%. Rand et al. (1963), Sawyer et al. (1963), Norman et al. (1964), Yeh et al. (1964), and Kulatilake and Shackman (1965) recorded their experience of patients requiring dialysis but did not quote the incidence of mild and severe renal failure in their cases. Porter et al. (1966), using blood urea values greater than $95 \mathrm{mg} / 100 \mathrm{ml}$ as the index, reported an incidence of mild renal failure of $44 \%$. In the present series the mortality was $38 \%$ when the renal failure was mild and $70 \%$ when it was severe $\left(\chi_{1}^{2}=5.75, P=0.02\right)$, and this high mortality is similar to that reported by Norman et al. (1964). But whether the renal failure was mild or severe the overall mortality was high $(43 \%)$ and contrasts strikingly with the low mortality rate of $3 \%$ in those cases without renal failure.
Inevitably in the cases coming to necropsy with renal failure the causes of death were multifactorial and in most cases there were cardiac, respiratory, and hepatic factors.

The causes of renal failure could be satisfactorily explained in almost half of our fatal cases subjected to necropsy-acute tubular necrosis in 10, renal infarction in seven, and pyaemic abscesses of the kidney in two. Microemboli of fat, cell debris, fibrin, or air (Grismer et al., 1964; Yeh et al., 1964; Porter et al., 1967) could have been responsible for the renal infarcts and pyaemic abscesses of the kidneys but were not found histologically. In the others, however, apart from mild tubular necrosis in three and old surface scars, venous congestion, and interstitial oedema in nine, there were no significant changes to account for the renal failure, and the azotaemia was thought to have been extrarenal and secondary to pulmonary embolism, congestive cardiac failure, or myocardial infarction. All the cases without significant renal lesions at necropsy were in the mild renal failure group; and in the absence of renal biopsy specimens it is not known what proportion of the non-fatal cases of renal impairment had "extrarenal" causes for the azotaemia.

The incidence of renal impairment was significantly greater in our patients with the higher preoperative blood ureas, a finding similar to that reported by Porter et al. (1967). The incidence of renal impairment in the present series was certainly greater when the perfusion was longer than 60 minutes (Grismer et al., 1964; Yeh et al., 1964; Porter et al., 1967) and was less when the mean perfusion pressure was maintained above $80 \mathrm{~mm}$ Hg (Osborn et al., 1964; Porter et al., 1966). Our longer perfusions reflected the more complicated cases. The incidence of renal impairment was greater after multiple valve replacement operations (Grismer et al., 1964; Yeh et al., 1964; Porter et al., 1966). There did not seem to be any relation between the age of individual patients or the degree of cooling and postoperative blood urea values $(r=0.03, P=0.38$ and $r=0.34, P=0.38$ respectively). An increased incidence of renal failure in patients over the age of 50 has been reported by Porter et al. (1967).

Evidence to support a claim that diuretics can be beneficial in some cases of renal failure (Yeh et al., 1964; Luke et al., 1965; Shackman and Kulatilake, 1971) was lacking in the present series. The mild cases of renal failure were managed by accepted conservative measures (Luke et al., 1965; Kulatilake and Shackman, 1965; de Wardener, 1967; Wrong, 1971). In the severe cases requiring dialysis peritoneal dialysis was preferred. It was effective, the patient did not need to be moved from the intensive care unit, and specialized nursing staff and equipment were not required (Norman et al., 1964; Kulatilake and Shaciman, 1965; Shackman and Kulatilake, 1971). However, when technical problems such as leakage of dialysate through the thoracotomy wound occurred it was necessary to use haemodialysis.

Although this study has shown a relatively high incidence of acute renal failure $(31 \%)$ in only $3.3 \%$ was the renal failure severe enough to cause death. However, though the overall mortality in the cases with acute renal failure was $43 \%$ the causes of death were usually extrarenal.

Acknowledgement is made to Professor R. Shackman for his guidance and useful advice in the preparation of this work; to Professor D. Melrose, Professor H. H. Bentall, and Mr. W. P. Cleland for allowing us to study patients under their care; and to Mrs. J. Rouse and Mrs. S. Willett for their secretarial work.

\section{References}

Bull, G. M., Joekes, A. M., and Lowe, K. G., (1950). Clinical Science, 9, 379. Grismer, J. T., Levy, M. J., Lillehei, R. C., Indeglia, R., and Lillehei, C. W. (1964). Surgery, 55, 24.

Kulatilake, A. E., and Shackman, R. (1965). Excerpta Medica International Congress Series, 103, 35.

Luke, R. G., Briggs, J. D., and Kennedy, A. C. (1965). Lancet, 1, 980. 
Norman, J. C., McDonald, H. P., and Sloan, H. (1964). Surgery, 56, 240. Osborn, J. J., et al. (1964). Bulletin de la Société Internationale de Chirurgie, 23, 555 .

Porter, G. A., Kloster, F. E., Herr, R. J., and Starr, A. (1966). Circulation, 34, 1005 .

Porter, G. A., Kloster, F. E., Herr, R. J., and Starr, A. (1967). fournal of Thoracic and Cardiovascular Surgery, 53, 145.

Rand, P. W., Austin, W. H., and Chatterjee, M. Surgery, 53, 456.
Sawyer, K. C., Sawyer, R. B., and Robb, W. C. (1963). American fournal of Surgery, 106, 668

Selmonsky, C. A. (1969). Archives of Surgery, 99, 64.

Shackman, R., and Kulatilake, A. E. (1971). British Medical Bulletin, 27, 103. de Wardener, H. E. (1967). The Kidney, p. 106. London, Churchill.

Wrong, O. (1971). British Medical Bulletin, 27, 97.

Yeh, T. J., Brackney, E. L., Hall, D. P., and Ellison, R. G. (1964). fournal of Thoracic and Cardiovascular Surgery, 47, 79.

\section{MEDICAL MEMORANDA}

\section{Arthropathy in Transfusional Siderosis}

\author{
D. F. ABBOTT, G. A. GRESHAM
}

British Medical fournal, 1972, 1, 418-419

Arthopathy as a complication of idiopathic haemochromatosis was described in 1964 (Schumacher). It has since been recognized with increasing frequency, and descriptions of the joint changes have been recorded (Hamilton, Williams, Barlow, and Smith, 1968; Wardle and Patten, 1969; Dymock, Hamilton, Laws, and Williams, 1970). The metacarpophalangeal joints are usually affected and some patients have involvement of larger joints.

There have been no reports of arthropathy occurring in transfusional siderosis.

\section{Case Report}

A 60-year-old woman presented with congestive cardiac failure in December 1962. She did not have arthritis and there were no features of haemochromatosis. Haemoglobin was $5 \cdot 1 \mathrm{~g} / 100 \mathrm{ml}$, the red cells being normochromic and normocytic. The peripheral white cell and platelet counts were normal. There was no evidence of haemolysis or of bleeding into the gastrointestinal or urinary tract. Bone biopsy showed sparse haemopoietic cells which were mostly of the myeloid series. The red cell precursors were mainly early and intermediate normoblasts with a scarcity of late forms.

A diagnosis of hypoplastic anaemia was made and it was subsequently necessary to readmit her for blood transfusion at intervals of between 2 and 10 weeks. Haemoglobin was kept in the range 6-12 $\mathrm{g} / 100 \mathrm{ml}$. Treatment with various haematinics including iron supplements did not reduce the transfusion requirements. After one year of treatment the serum iron was $161 \mu \mathrm{g} / 100 \mathrm{ml}$ and the total iron binding capacity $200 \mu \mathrm{g} / 100 \mathrm{ml}$. The iron supplements were therefore stopped. In December 1966 the serum iron had risen to $267 \mu \mathrm{g} / 100 \mathrm{ml}$ and daily desferrioxamine was started. When she became anaemic congestive cardiac failure recurred. She was therefore treated with digoxin and diuretics.

In March 1967, by which time she had received a total of 166 units of blood, she developed acute polyarthritis. The knees, ankles and wrists, and the left shoulder were painful, swollen, and had limited movement. No abnormality was detected in the spine or in the small joints of the hands and feet. Rheumatoid nodules were not found.

Investigations were: M.C.H.C. $34.5 \%$, E.S.R. $143 \mathrm{~mm}$ in one hour, uric acid $3.6 \mathrm{mg} / 100 \mathrm{ml}$, Rose-Waaler test negative, and lupus erythematosus cells not found. The joints were not $x$-rayed at that

Addenbrooke's Hospital, Cambridge

D. F. ABBOTT, M.B., B.S., M.R.C.P., Medical Registrar

G. A. GRESHAM, M.D., M.R.C.PATH., Honorary Consultant in Pathology time but a chest $x$-ray examination the following year showed opacification in the synovium of the left shoulder which was not seen on previous films.

Enteric-coated aspirin was effective in relieving the symptoms and this was continued until November 1967, when the arthritis subsided. She experienced no further joint symptoms until March

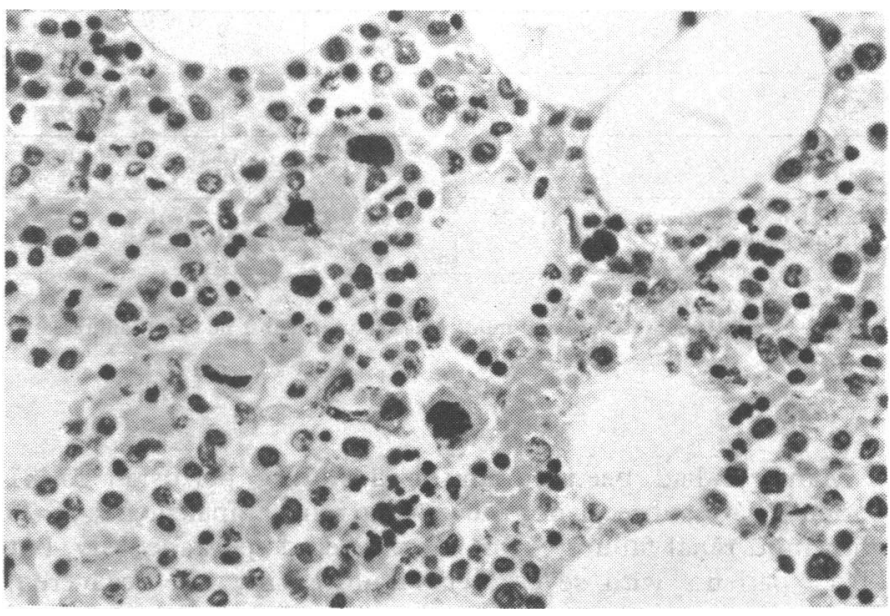

FIG. 1-Femoral bone marrow showing abundant megakaryocytes. (Haematoxylin and eosin. $\times 262$.)

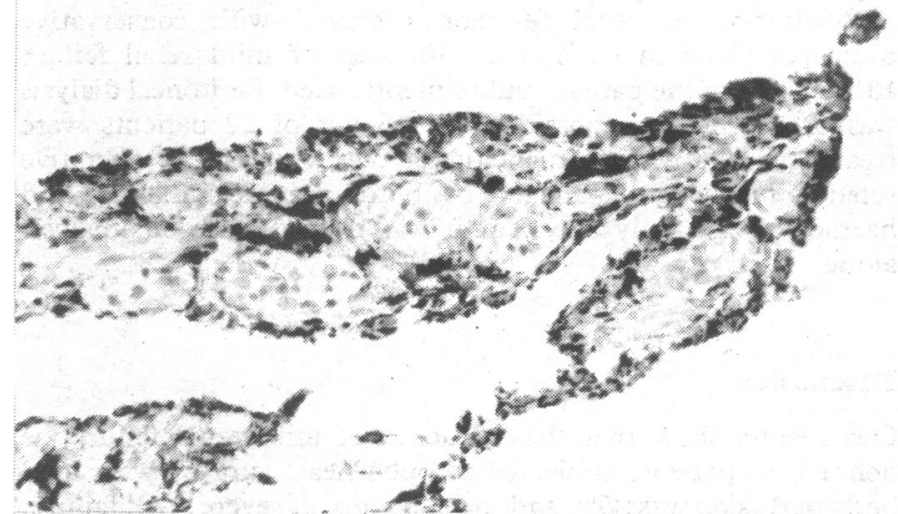

FIG. 2-Synovium of right knee joint containing abundant pigment in surface and deep cells. (Perls' stain. $\times$ 163.)

1969, when she complained of aching in all limb joints. By August this had become severe. At that time she had been transfused a total of 272 units of blood. She died suddenly of cerebral haemorrhage in September 1969.

Necropsy. - The body was that of a pale old woman with slight oedema of the lower legs and ankles. The left cerebral hemisphere contained a large blood clot. There was conspicuous brownish discoloration of the synovium of the right hip, knee, and ankle joints but not of the sternoclavicular joints. The shoulder and finger joints were not examined. The upper half of the femur contained 